\title{
ПРЕДПОСЫЛКИ ВЫДЕЛЕНИЯ УСМОТРЕНИЯ ОРГАНОВ КОНТРОЛЯ И НАДЗОРА В КАЧЕСТВЕ ОСОБОЙ РАЗНОВИДНОСТИ ПРАВОВОЙ ДИСКРЕЦИИ
}

\author{
(C) 2020 Никитин Александр Александрович \\ кандидат юридических наук, доцент кафедры прокурорского надзора и криминологии \\ Саратовская государственная юридическая академия, Россия, Саратов \\ E-mail: alexnik-82@mail.ru
}

В статье рассматривается содержание и специфика контрольной и надзорной деятельности, обуславливающие особенности правового усмотрения субъектов, осуществляющих данные виды деятельности. Делается вывод, что особенности государственной проверочной деятельности в сравнении с другими видами правоприменительной деятельности предполагают необходимость отдельного исследования дискреции органов контроля и надзора, как особой разновидности правового усмотрения.

Ключевые слова: проверочная деятельность, контроль, надзор, правоприменительное усмотрение, вид правовой дискреции.

В исследовании правоприменительного усмотрения отдельное внимание следует уделить изучению усмотрения органов контроля и надзора, действующих в государстве. Необходимость специального исследования именно этой сферы реализации правоприменительного усмотрения обусловлена рядом обстоятельств.

Во-первых, важностью самой проверочной (контрольной, надзорной) деятельности. С одной стороны, такая деятельность является необходимым элементом руководства и управления, которые пронизывают не только всю работу государственных органов и органов местного самоуправления, но и всю деятельность коммерческих и некоммерческих организаций всех форм собственности и любых организационноправовых форм. С другой стороны, контроль и надзор имеют самостоятельное значение как важнейшее направление деятельности специальных государственных и муниципальных органов и их должностных лиц.

Во-вторых, многочисленностью органов и должностных лиц, уполномоченных осуществлять контрольную и надзорную деятельность. Так, в системе органов исполнительной власти функциями по контролю и надзору в общем порядке наделены все федеральные службы, а в случаях, определенных указами Президента РФ и постановлениями Правительства РФ, также федеральные министерства и федеральные агентства. На 2018 г. в Российской Федерации в сумме насчитывалось более 200 видов государ- ственного контроля (надзора), осуществляемого федеральными органами исполнительной власти и региональными органами государственной власти, а также муниципального контроля [1].

Кроме органов исполнительной власти, существуют и иные органы, осуществляющие контрольные и надзорные функции (Счетная палата РФ, Прокуратура РФ и др.).

В-третьих, с работой контрольных и надзорных органов или ее результатами граждане соприкасаются как в ходе служебной деятельности, так и в быту. Достаточно назвать Федеральную службу по надзору в сфере защиты прав потребителей и благополучия человека (Роспотребнадзор) и действующие в регионах государственные жилищные инспекции, контрольно-надзорные полномочия которых распространяются на очень широкие пласты общественных отношений с участием подавляющего большинства населения страны.

В-четвертых, специфика контрольно-надзорной деятельности предполагает необходимость определения и сохранения баланса между защитой прав и законных интересов подконтрольных и поднадзорных органов, организаций и лиц от злоупотреблений полномочиями со стороны проверяющих и обеспечением эффективности контроля и надзора. Установление такого баланса напрямую зависит от качества нормативно-правового регулирования контрольно-надзорной деятельности, в том 
числе законодательной регламентации пределов усмотрения уполномоченных органов и лиц. Излишняя свобода усмотрения, предоставленная контрольным и надзорным органам, создает условия для злоупотреблений с их стороны, нарушений прав и законных интересов граждан и юридических лиц, дестабилизации экономической и социальной ситуации в стране. Но при этом неоправданные ограничения конкретнонормативного или компетенционного усмотрения органов контроля и надзора делают эту деятельность низкоэффективной, что так же является угрозой для безопасности граждан, общества и государства.

Перечисленные обстоятельства демонстрируют большое значение, которое имеет контрольно-надзорная деятельность для нормального развития общества и государства.

Исследование усмотрения контрольных и надзорных органов предполагает необходимость определения содержания контроля и надзора и их соотношения друг с другом.

Словарные определения понятий «контроль» и «надзор» пересекаются между собой, демонстрируя близость значений названных терминов. Так, в словаре живого великорусского языка В.И.Даля термин «надзор» определяется как присмотр, наблюдение, а «надзиратель» - смотритель, надсмотрщик [2]. В других словарных источниках под надзором понимают «наблюдение, присмотр за кем-либо, чем-либо с целью контроля, охраны; наблюдение с целью присмотра; наблюдение специальных учреждений органов власти с целью контроля» [3].

Понятие «контроль» в словарях определяется как «наблюдение и проверка [4]; проверка, наблюдение в целях проверки [5]». То есть словарные источники дают очень близкое толкование названных терминов, сводя их содержание к единому значению - деятельность по проверке и наблюдению.

Юридической наукой предлагаются более развернутые определения понятий «контроль» и «надзор», отражающие характерные черты каждого термина и их различия.

Так, В.П.Беляев определяет контроль как форму юридической деятельности, при которой управомоченные органы и лица в рамках контрольного производства осуществляют сбор и проверку информации о фактическом выполнении нормативных предписаний и непосредственно применяют меры по предупреждению и пресечению допущенных нарушений требований нормативно-правовых актов. Под надзором данный автор понимает автономную форму юридической деятельности управомоченных субъектов, направленную на выявление, пресечение и предупреждение нарушений законов и заключающуюся в разрешении на поднадзорных объектах конкретных юридических дел, связанных с неисполнением или ненадлежащим исполнением законов. Исходя из таких определений автор делает вывод о том, что функция надзора присуща только прокуратуре РФ, а другие органы, в первую очередь такие органы исполнительной власти, как федеральные службы, выполняют функцию контроля. В связи с этим он находит целесообразным заменить используемый в названии федеральных служб термин «надзор» на «контроль» [6].

Во многом аналогичное мнение относительно понятия контроля и надзора и их соотношения высказывает В. В. Дьяконов. Он полагает, что контроль - это деятельность государственных органов по обеспечению эффективного и целесообразного функционирования государства путем проверки соответствия фактического состояния общественных отношений юридическим нормам. Надзор он рассматривает как особую разновидность специального государственного контроля правоохранительных органов, обеспечивающую законность посредством реагирования на ее нарушения [7]. В приведенных определениях акцент также делается на том, что предметом надзорной деятельности выступает законность, и такая деятельность является более узкой по сравнению с контрольной.

Кроме указания на специфику предмета деятельности, контроль и надзор различают по объему и характеру полномочий, которыми обладают соответствующие органы и лица. Так, например, Н.М.Конин полагает, что контроль включает в себя проверку фактического результата, путей и средств его достижения, а также принятие мер позитивного или негативного характера по итогам контроля. Надзор же исчерпывается проверкой результата на соблюдение нормативного предписания [8]. А.П.Алехин и А.А.Кармолицкий в качестве особенностей отмечают, что в процессе контроля могут применяться меры дисциплинарного воздействия, а в процессе надзора - административного [9].

Анализ подходов к определению содержания контроля и надзора позволяет сделать вывод о 
том, что данные понятия являются взаимосвязанными, но не тождественными, поскольку отражают особенности двух видов проверочной юридической деятельности: контрольной и надзорной.

Действующее законодательство использует термины «контроль» и «надзор» совместно, из чего можно сделать вывод, что эти виды деятельности рассматриваются как самостоятельные, но при этом близкие по целям, задачам, правовой регламентации, субъектам их осуществляющим. Однако нормативно-правовые акты не дают однозначного ответа на вопрос о различиях между контролем и надзором. Так, в подпункте «б» пункта 2 Указа Президента РФ от 9 марта 2004 г. № 314 «О системе и структуре федеральных органов исполнительной власти» устанавливается, что понимается под функциями по контролю и надзору, которыми наделяются органы исполнительной власти: осуществление действий по контролю и надзору за исполнением государственными и муниципальными органами, их должностными лицами, юридическими лицами и гражданами установленных нормативноправовыми актами общеобязательных правил поведения; выдача лицензий (разрешений) на занятие определенной деятельностью; регистрация актов, документов, прав и объектов [10]. В ст. 2 Федерального закона от 26 декабря 2008 г. № 294-Ф3 «О защите прав юридических лиц и индивидуальных предпринимателей при осуществлении государственного контроля (надзора) и муниципального контроля» [11] даются законодательные дефиниции «государственного контроля (надзора)», «федерального государственного контроля (надзора)», «регионального государственного контроля (надзора)» и «муниципального контроля». Основываясь на содержании названной статьи, можно сделать два вывода. Во-первых, надзор не осуществляется органами местного самоуправления и за исполнением предписаний, содержащихся в нормативно-правовых актах органов местного самоуправления. Во-вторых, элементы, которые в соответствии с п. 1 ст. 2 указанного закона составляют содержание государственного контроля (надзора): деятельность уполномоченных органов, направленная на предупреждение, выявление и пресечение нарушений требований, установленных нормативно-правовыми актами, осуществляемая посредством проведения проверок, профилактических мероприятий, меро- приятий, осуществляемых без взаимодействия с юридическими лицами и индивидуальными предпринимателями, присущи как собственно контролю, так и надзору. В других законах использование понятий «надзор» (прокурорский надзор [12]) и «контроль» (например, лицензионный контроль [13]) не сопровождается разъяснением специфики этого вида проверочной деятельности по сравнению с другим. Следовательно, устанавливать различия необходимо на основе анализа полномочий проверяющих органов, особенностей предмета проверок, их организации.

Рассматривая специфику контроля и надзора, следует обратить внимание на критерии, по которым проводится их дифференциация. Как правило, в качестве таких критериев выделяют: отношение подчиненности, предмет проверок, объем полномочий проверяющих органов и лиц. Следует согласиться с авторами, которые на основе названных критериев определяют следующие основные отличия надзора от контроля:

а) при надзоре отсутствуют отношения подчиненности проверяемых органов надзирающим, а при контроле такое подчинение возможно. Исходя из этого, надзор свободен от признаков руководства и управления и носит по отношению к проверяемому объекту только внешний характер, а контроль может быть как внешним, так и внутренним, связанным с управленческой деятельностью;

б) в процессе надзора оценивается деятельность и ее результаты с позиции соответствия нормативным предписаниям (прежде всего, правовым), тогда как при контроле оценке могут подлежать целесообразность и эффективность деятельности;

в) возможность вмешательства в оперативно-хозяйственную деятельность проверяемого органа может существовать при контроле и отсутствует при надзоре;

г) отсутствие возможности у должностных лиц надзорных органов самостоятельно принимать меры к устранению выявленных нарушений и применять меры дисциплинарного воздействия на лиц, допустивших нарушения. Органы контроля могут обладать соответствующими полномочиями [14].

Перечисленные отличия будут определять объем дискреционных полномочий контрольных органов и надзорных, а также уровень свободы усмотрения, которой они обладают. Оче- 
видно, что отношения подчиненности, которые могут быть у контролирующего органа с проверяемым, предполагают наличие у контролирующего органа большей свободы в выборе вариантов предупреждения, профилактики, устранения допущенных нарушений, чем у надзорного.

Названные особенности отличают контроль от надзора, однако они не отражают их соотношения. В литературе отсутствует единообразный подход к определению соотношения контроля и надзора. Можно выделить три основных точки зрения на соотношение данных понятий. В рамках первого подхода контроль рассматривается как более общее понятие, включающее в себя надзор [15]. В рамках этого подхода существует небольшой разброс мнений относительно характеристик надзора - является ли он особой разновидностью контроля, либо не обладает специфическими чертами и идентичен последнему.

Согласно второй точке зрения, наоборот, понятие «надзор» следует рассматривать как более общее, включающее контроль. В частности, О. С. Соколова приходит к такому выводу, исходя из анализа определений основных понятий, используемых в законе «О защите прав юридических лиц и индивидуальных предпринимателей при осуществлении государственного контроля (надзора) и муниципального контроля». Она отмечает, что если законодатель под проверкой понимает совокупность мероприятий по контролю, проводимых уполномоченными органами контроля и надзора, то контроль является частью надзора, поскольку последний включает в себя проведение проверок [16]. Такой вывод представляется крайне спорным, в связи с тем, что не только надзор, но и контроль включает в себя проведение проверок, и с этой точки зрения, как разновидность проверочной деятельности, контроль равнозначен надзору.

Наиболее оптимальным представляется третий подход, в рамках которого предлагается различать широкое понимание контроля как социально-правового явления или системы государственного контроля. Данное явление находит свое выражение в двух самостоятельных видах деятельности - надзоре и разновидностях собственно контроля (парламентский, президентский, органов исполнительной власти и др.) [17]. Представляется допустимым термин «контроль», используемый в широком смысле, заменять на «проверочную деятельность», имеющую две разновидности: контрольную (соответствующие виды контроля - президентский, парламентский, судебный и т.п.) и надзорную.

Таким образом, изложенные обстоятельства позволяют сделать ряд выводов.

Во-первых, проверочная деятельность, осуществляемая в форме контроля или надзора, имеет определенные особенности по сравнению с иными видами правоприменения. Проведение контрольных или надзорных мероприятий является властной формой реализации правовых норм, закрепляющих полномочия соответствующих органов. Однако не всегда такая деятельность завершается вынесением правоприменительного акта. Это означает, что усмотрение контролирующего или надзорного органа может быть выражено не только в правоприменительном акте, но и в иных деяниях должностных лиц этих органов (например, при отсутствии нарушений обязательных требований в деятельности проверяемого субъекта, документ реагирования не составляется, а результаты проверочных мероприятий могут быть отражены в справке или акте проверки).

Во-вторых, излишнее законодательное ограничение дискреционных полномочий проверяющих органов может привести к снижению эффективности контрольных и надзорных мероприятий. Это обусловлено тем, что достижение цели проверки - максимально полное и своевременное выявление всех допущенных нарушений в деятельности проверяемого субъекта, обеспечивается широкой вариативностью действий проверяющих.

\section{Библиографический список}

1. Евсиков К. С., Спиридонов А. А. Повышение уровня защиты конституционных прав и свобод человека в свете реформы государственного контроля (надзора) и муниципального контроля в Российской Федерации // Известия Тульского государственного университета. Экономические и юридические науки. 2018. № 3-2. С. 69.

2. Даль В. Толковый словарь живого великорусского языка: В 4 т. М.: Рус. яз., 1998. Т. 2: И - О. 1998. С. 401. 
3. Ожегов С.И. Толковый словарь русского языка: Около 100000 слов, терминов и фразеологических выражений / С. И. Ожегов; Под ред. проф. Л. И. Скворцова. 27-е изд., испр. М.: Изд-во АСТ; Мир и образование, 2018. C. 570 .

4. Краткий толковый словарь русского языка (для иностранцев) / Под ред. В.В.Розановой. М.: Изд-во «Русский язык», 1978. С. 72.

5. Словарь русского языка: В 4-х т. / АН СССР, Ин-т рус. яз.; Под ред. А. П.Евгеньевой. 2-е изд., испр. и доп. М.: Русский язык, 1981-1984. Т. 2. 1982. С. 94.

6. Беляев В.П. Контроль и надзор как формы юридической деятельности: Вопросы теории и практики: автореф. дис.... д-ра юрид. наук. Саратов, 2006. С. 11-13.

7. Дьяконов В.В. Контроль и надзор в системе функций государства (теоретический аспект): автореф. дис. ... канд. юрид. наук. М., 2006. С. 12.

8. Конин Н. М. Административное право России. Общая и Особенная части: курс лекций. М.: Юристъ, 2004. С. 235.

9. Алехин А.П., КармолицкийА.А. Административное право России: учебник для юридических вузов и факультетов. М.: Зерцало-М, 2007. С. 404.

10. Собр. законодательства Рос. Федерации. 2004. № 11. Ст. 945; 2019. № 15 (ч. 1). Ст. 1727.

11. Собр. законодательства Рос. Федерации. 2008. № 52 (часть 1). Ст. 6249; 2020. № 29. Ст. 4504.

12. Федеральный закон от 17 января 1992 г. (в ред. от 27 октября 2020 г.) № 2202-1 «О прокуратуре Российской Федерации» // Ведомости СНД РФ и ВС РФ. 1992. № 8. Ст. 366; Собр. законодательства Рос. Федерации. 2020. № 44. Ст. 6895.

13. Федеральный закон от 4 мая 2011 г. (в ред. от 31 июля 2020 г.) № 99-Ф3 «О лицензировании отдельных видов деятельности» // Собр. законодательства Рос. Федерации. 2011. № 19. Ст. 2716; 2020. № 31 (часть 1). Ст. 5029.

14. Богатова E. В. Контрольно-надзорная деятельность и ее эффективность в стадии возбуждения уголовного дела: монография. М.: Юрлитинформ, 2018. С. 9.

15. Авакьян С. А., Барабашев Г.В. Советы и совершенствование деятельности местных контрольных органов // Вестник Московского университета. Серия «Право». 1984. № 1. С. 14.

16. Соколова О.С. Понятие и содержание муниципального контроля // Современное право. 2009. № 10. С. 77.

17. Гейвандов Я.А. Содержание и основные направления государственной надзорно-контрольной деятельности в банковской сфере // Юрист. 2000. № 6. С. 24. 